\title{
COMPARISON OF THREE TYPES OF AEROSOL PRODUCTS DURING 2015-2017 IN CHINA
}

\author{
Suyuan $\mathrm{Li}^{1}$, Feng Zhang ${ }^{1,2 *}$, Qiu-Run $\mathrm{Yu}^{1}$, Ka Lok $\mathrm{Chan}^{3}$,Can $\mathrm{Hou}^{4}$, Rong Guo ${ }^{5}$, Mingkeng Duan ${ }^{1,2}$
}

1 Key Laboratory of Meteorological Disaster, Ministry of Education (KLME)/ Collaborative Innovation Center on Forecast and Evaluation of Meteorological Disaster (CIC-FEMD), Nanjing University of Information Science and Technology, Nanjing, 210044, China

2 Key Laboratory of Severe Weather, Chinese Academy of Meteorological Sciences, Beijing, 100081, China

3 Remote Sensing Technology Institute, German Aerospace Center (DLR), Oberpfaffenhofen, Germany

4 Key Laboratory of Atmospheric Sciences and Satellite, Remote Sensing of Anhui Province, Anhui Institute of Meteorological Sciences, Hefei, 230031, China

5 Shanghai Central Meteorological Observatory, Shanghai, 200030, China

KEY WORDS: Aerosol Optical Depth, MODIS, Himawari-08, MERRA-2, Comparison

\begin{abstract}
:
In this study, we use sunphotometer (AERONET) data as reference to evaluate MODIS, Himawari-08, and MERRA-2 aerosol products over China. AERONET data from Beijing, Xianghe, Xuzhou, Taihu and Hong Kong are used. The results indicate that aerosol optical depths (AODs) obtained from MODIS, Himawari-08, and MERRA-2 from 2015-2017 over China are consistent with the AERONET observations. The accuracy of these AOD products shows a spatial and temporal variation. MODIS aerosol products tend to overestimate the AODs at Beijing, Xianghe and Xuzhou, with stronger overestimation in winter. For Taihu and Hong Kong, MODIS only overestimates the AODs in winter. Himawari-08 and MERRA-2 underestimate the AODs in autumn over almost all stations except Taihu.
\end{abstract}

\section{INTRODUCTION}

Atmospheric aerosols participate directly or indirectly in radiative forcing processes and cloud-forming processes, and have an extremely important impact on global climate change. By directly scattering or absorbing sunlight, aerosols can alter surface albedo and influence radiative budget. Therefore, increasing attentions have been paid to accurately determine the aerosol radiative effects in recent years ${ }^{[1-5]}$. In the study of atmospheric aerosols, people often have to obtain aerosol data all over the world. But, due to the limitation of the number of ground-based observation sites, it is not conducive to derive global aerosol properties for researches worldwide. Satellite remote sensing measurements can fill in these huge data voids and achieve global coverage easily. However, influenced by surface characteristics and weather conditions easily, the accuracy of satellite inversion data is lower than that of groundbased observations. So it is necessary that the accuracy of the aerosol products should be verified before they can be put into use ${ }^{[6]}$.

With the development of measurement techniques and radiative transfer calculations, varies of satellite aerosol data products are available. Nowadays MODIS, Himawari-08 and MERRA-2 aerosol products are widely used as they provide aerosol optical properties with high spatial and temporal resolution on a global scale. Since the 1990s, the inversion algorithm of MODIS aerosol products has been developed for more than 20 years and the accuracy of data is constantly improving ${ }^{[7-8]}$. Munchak et al. developed a new algorithm (MxD04 3K) for the inversion of aerosol optical properties from MODIS observations ${ }^{[9]}$. Wang et al. conducted an accuracy test of MODIS data over China ${ }^{[10]}$. Zhang et al. validated the MODIS C6 AOD product based on a station in the Beijing-Tianjin-Hebei areas ${ }^{[11]}$.

Different from MODIS aerosol products, Himawari-08 aerosol products have the advantages of higher spatial and temporal resolutions and more detection channels including the band 3 $(0.64 \mu \mathrm{m})$, band $4(0.86 \mu \mathrm{m})$, and band $6(2.3 \mu \mathrm{m})^{[12-13]}$. As the Japanese geostationary meteorological satellite Himawari-08 is located at $140.7^{\circ} \mathrm{E}$, which was launched in October 2014 , its aerosol products provide important information of aerosol distribution over East Asia. Lots of efforts have been done to improve the algorithm of Himawari-08 aerosol products. Fukuda et al. proposed an improved Kaufman algorithm for the inversion of aerosol optical properties from Himawari-08 observations ${ }^{[14]}$. Zhang et al. proposed an improved algorithm for monitoring and forecasting air quality from Himawari8/AHI over East Asia ${ }^{[15]}$. However, there is less work on the accuracy of Himawari-08 aerosol products.

The Modern-Era Retrospective Analysis for Research and Applications, version 2 (MERRA-2) from the NASA Global Modeling and Assimilation Office is the new modern satellite era [16]. To our knowledge, MERRA-2 assimilates numerous data sets, like the assimilation of bias-corrected AOD from the Advanced Very High Resolution Radiometer (AVHRR) instruments and analyzed aerosol fields that are radiatively coupled to the atmosphere ${ }^{[17]}$. Because of using a larger number of new observations than MERRA, MERRA-2 has made a huge improvement in many aspects. Like MODIS and Himawari-08 aerosol products, the accuracy of its distribution characteristics also has to be evaluated. In addition, the validation of MERRA-2 aerosol product is also necessary.

In previous studies, validation is mainly focused on MODIS aerosol products ${ }^{[7-11]}$, and the result shows that the accuracy of MODIS aerosol products is constantly improving. However, there are not much work about the evaluation of Himawari-08 and MERRA-2 aerosol products. Based on this starting point, this paper evaluates the accuracy and applicability of three satellite aerosol products, MODIS, Himawari-08 and MERRA2, choosing Beijing, Xianghe, Xuzhou, Taihu and Hong Kong as representative stations, and analyzes regional and seasonal differences.

\section{DATA AND METHODS}

\subsection{MODIS, Himawari-08, MERRA-2 and AERONET AODs}

The MODIS data set used in our analysis is Terra and Aqua MODIS AOD products (MOD04_L2) at 550nm, covering the 
time period from January 2015 to December 2017 with the spatial resolution of $10 \mathrm{~km} \times 10 \mathrm{~km}^{[1]}$. The Himawari- 08 data set used in our analysis covers the time period from July 2015 to December 2017 with the spatial resolution of $5 \mathrm{~km} \times 5 \mathrm{~km}{ }^{[2]}$. The MERRA-2 data set used in our analysis covers the time period from January 2015 to December 2017 with the spatial resolution of $0.5^{\circ}$ latitude $\times 0.625^{\circ}$ longitude ${ }^{[3]}$.

The sunphotometer (AERONET) data is used as the benchmark result. In our study, the AERONET stations in Beijing, Xianghe, Xuzhou, Taihu and Hong Kong are chosen as representative stations (see Table 1). The effects of the complicated underlying surface condition are considered in the analysis of the aerosol characteristics ${ }^{[10]}$.

Table 1. Observation time and level of AERONET AODs in the representative stations

\begin{tabular}{ccccc}
\hline Area & Station & $\begin{array}{c}\text { longitude and } \\
\text { latitude }\end{array}$ & Level & $\begin{array}{c}\text { Time } \\
\text { Period }\end{array}$ \\
\hline North & Beijing & $\begin{array}{r}\left(116.381^{\circ} \mathrm{E},\right. \\
\left.39.977^{\circ} \mathrm{N}\right)\end{array}$ & 2.0 & $\begin{array}{c}2015.01- \\
2017.05\end{array}$ \\
China & Xianhe & $\begin{array}{r}\left(116.962^{\circ} \mathrm{E},\right. \\
\left.39.754^{\circ} \mathrm{N}\right)\end{array}$ & 2.0 & $\begin{array}{c}2015.01- \\
2017.05\end{array}$ \\
& & & $2015.01-$ \\
$\left(117.142^{\circ} \mathrm{E}\right.$, & \multirow{2}{*}{1.5} & 2017.12 \\
East & Xuzhou & $\left.34.217^{\circ} \mathrm{N}\right)$ & & $2015.10-$ \\
China & Taihu & $\left(120.215^{\circ} \mathrm{E}\right.$, & 2.0 & 2016.08 \\
& $\left.31.421^{\circ} \mathrm{N}\right)$ & & $2015.01-$ \\
South & Hong & $\left(114.180^{\circ} \mathrm{E}\right.$, & 2.0 & 2017.03 \\
China & Kong & $\left.22.303^{\circ} \mathrm{N}\right)$ &
\end{tabular}

2.2 Methodology

Due to the lack of AERONET AOD data at 550nm, we use an interpolation method to interpolate AERONET AOD at 440nm and $675 \mathrm{~nm}$ to obtain the AOD data at $550 \mathrm{~nm}{ }^{[18]}$. The interpolation method is

$$
\begin{aligned}
A O T_{\lambda_{3}} & =A O T_{\lambda_{1}}\left(\frac{\lambda_{1}}{\lambda_{3}}\right)^{\alpha_{\lambda_{1}-\lambda_{2}}} \\
\alpha_{\lambda_{1}-\lambda_{2}} & =-\frac{\ln \left(\frac{A O T_{\lambda_{1}}}{A O T_{\lambda_{2}}}\right)}{\ln \left(\frac{\lambda_{1}}{\lambda_{2}}\right)}
\end{aligned}
$$

Where $\lambda_{1}, \lambda_{2}, \lambda_{3}$ respectively indicate different wavelengths, and $A O T_{\lambda_{i}}(i=1,2,3)$ are AERONET AODs at $440 \mathrm{~nm} 675 \mathrm{~nm}$ and $550 \mathrm{~nm}$, respectively.

For the purposes of comparison, AODs products of MODIS, Himawari-08, MERRA-2 and AERONET AODs in these five stations must be corresponded in space and time. The spacetime matching scheme is that MODIS, Himawari-08 and MERRA-2 AODs are averaged over a circular field with a radius of $50 \mathrm{~km}$, and AERONET AOD is averaged within half an hour before and after the satellite overpass.

\section{RESULTS AND DISCUSSIONS}

Figure 1 shows the scatter plots of MODIS AODs versus AERONET AODs in Beijing during different seasons. From Fig.1, it is obvious that MODIS AODs show good correlation with AERONET AODs in Beijing. The squared correlation coefficients for the linear regression fits $\mathrm{R}^{2}$ are $0.261,0.849$, 0.291 and 0.61 in the four seasons, respectively. The root mean square errors between MODIS and AERONET AODs are very close to zero ( 0.153 for spring, 0.038 for summer, 0.093 for autumn and 0.046 for winter). Moreover, the slopes of regression line are slightly higher than unity in summer and winter $(0.437$ for spring, 1.143 for summer, 0.574 for autumn and 1.167 for winter), indicating that MODIS AODs in Beijing tend to overestimate the AODs in summer and winter.
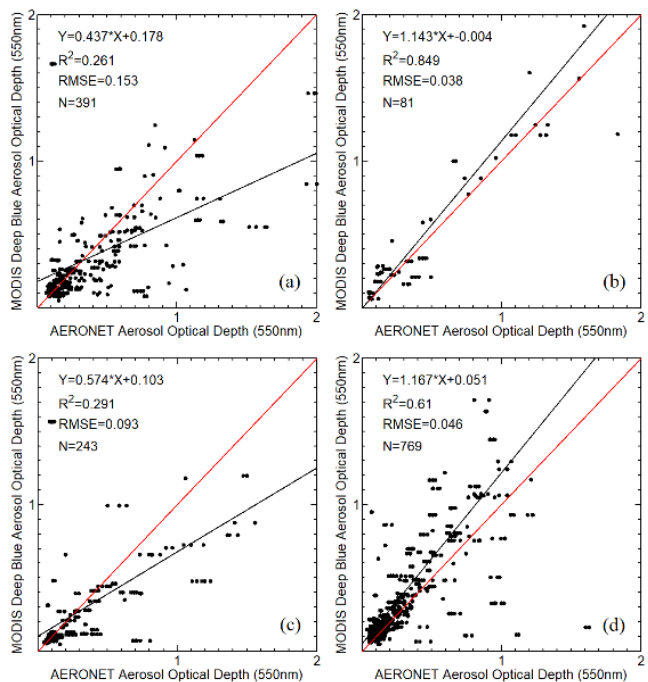

Figure 1. Scatter plots of MODIS AODs versus AERONET AODs in Beijing

(a) spring (b) summer (c) autumn (d) winter.

The black and red lines represent the slopes of linear regression and the 1:1 lines of scatter plots.

Figure 2 shows the scatter plots of Himawari-08 versus AERONET AODs in Beijing during the four seasons. From Fig.2, It is obvious that Himawari-08 AODs show good correlation with AERONET AODs in Beijing. The $\mathrm{R}^{2}$ are 0.463 , $0.766,0.625$ and 0.398 in the four seasons, respectively. The root mean square errors between Himawari-08 and AERONET AODs are very close to zero (0.077 for spring, 0.069 for summer, 0.082 for autumn and 0.075 for winter). Besides, the slopes of regression line are lower than unity ( 0.565 for spring, 0.497 for summer, 0.344 for autumn and 0.388 for winter). To put it differently, Himawari-08 AODs in Beijing tend to underestimate the AODs in every season.
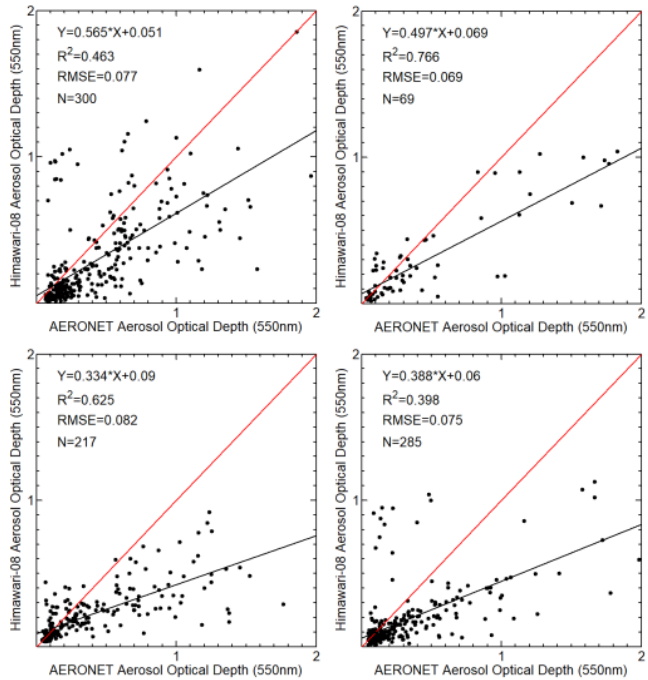

Figure 2. Scatter plots of Himawari-08 AODs versus AERONET AODs in Beijing

(a) spring (b) summer (c) autumn (d) winter. 
The International Archives of the Photogrammetry, Remote Sensing and Spatial Information Sciences, Volume XLII-3/W5, 2018 ISPRS Workshop on Remote Sensing and Synergic Analysis on Atmospheric Environment, 7-8 November 2018, Guangzhou, China

The black and red lines represent the slopes of linear regression and the 1:1 lines of scatter plots. 
The International Archives of the Photogrammetry, Remote Sensing and Spatial Information Sciences, Volume XLII-3/W5, 2018 ISPRS Workshop on Remote Sensing and Synergic Analysis on Atmospheric Environment, 7-8 November 2018, Guangzhou, China

Table 2. The squared correlation coefficients $\left(\mathrm{R}^{2}\right)$, the root mean square errors (RMSE) and the slopes (K) of regression lines of MODIS, Himawari-08, MERRA-2 comparing with AERONET AODs

\begin{tabular}{|c|c|c|c|c|c|c|c|c|c|c|c|}
\hline \multirow{2}{*}{ Area } & \multirow{2}{*}{ Station } & \multirow{2}{*}{ Season } & \multicolumn{3}{|c|}{ MODIS } & \multicolumn{3}{|c|}{ Himawari-08 } & \multicolumn{3}{|c|}{ MERRA-2 } \\
\hline & & & $\mathrm{R}^{2}$ & RMSE & $\mathrm{K}$ & $\mathrm{R}^{2}$ & RMSE & $\mathrm{K}$ & $\mathrm{R}^{2}$ & RMSE & K \\
\hline \multirow{8}{*}{$\begin{array}{l}\text { North } \\
\text { China }\end{array}$} & \multirow{4}{*}{ Beijing } & spring & 0.261 & 0.153 & 0.437 & 0.463 & 0.077 & 0.565 & 0.418 & 0.099 & 0.399 \\
\hline & & summer & 0.849 & 0.038 & 1.143 & 0.766 & 0.069 & 0.497 & 0.746 & 0.128 & 0.573 \\
\hline & & autumn & 0.291 & 0.093 & 0.574 & 0.625 & 0.082 & 0.344 & 0.349 & 0.198 & 0.324 \\
\hline & & winter & 0.610 & 0.046 & 1.167 & 0.398 & 0.075 & 0.388 & 0.526 & 0.059 & 0.465 \\
\hline & \multirow{4}{*}{ Xianhe } & spring & 0.541 & 0.103 & 0.620 & 0.599 & 0.088 & 0.595 & 0.458 & 0.159 & 0.400 \\
\hline & & summer & 0.788 & 0.086 & 1.173 & 0.772 & 0.103 & 0.566 & 0.571 & 0.235 & 0.610 \\
\hline & & autumn & 0.526 & 0.122 & 1.047 & 0.763 & 0.045 & 0.546 & 0.452 & 0.169 & 0.490 \\
\hline & & winter & 0.799 & 0.032 & 1.284 & 0.429 & 0.074 & 0.419 & 0.443 & 0.083 & 0.416 \\
\hline \multirow{8}{*}{$\begin{array}{c}\text { East } \\
\text { China }\end{array}$} & \multirow{4}{*}{ Xuzhou } & spring & 0.411 & 0.058 & 0.760 & 0.413 & 0.072 & 0.548 & 0.219 & 0.153 & 0.280 \\
\hline & & summer & 0.925 & 0.037 & 1.028 & 0.553 & 0.118 & 0.602 & 0.408 & 0.192 & 0.411 \\
\hline & & autumn & 0.156 & 0.081 & 0.684 & 0.571 & 0.060 & 0.525 & 0.609 & 0.062 & 0.843 \\
\hline & & winter & 0.819 & 0.019 & 1.332 & 0.566 & 0.044 & 0.601 & 0.225 & 0.077 & 0.377 \\
\hline & \multirow{4}{*}{ Taihu } & spring & 0.452 & 0.032 & 0.428 & 0.408 & 0.050 & 0.804 & 0.308 & 0.057 & 0.667 \\
\hline & & summer & 0.059 & 0.025 & 0.208 & 0.412 & 0.049 & 0.720 & 0.370 & 0.052 & 0.527 \\
\hline & & autumn & 0.337 & 0.017 & 0.701 & 0.658 & 0.016 & 1.010 & 0.655 & 0.016 & 1.343 \\
\hline & & winter & 0.872 & 0.009 & 1.081 & 0.154 & 0.050 & 0.403 & 0.481 & 0.030 & 0.663 \\
\hline \multirow{4}{*}{$\begin{array}{l}\text { South } \\
\text { China }\end{array}$} & \multirow{4}{*}{$\begin{array}{l}\text { Hong } \\
\text { Kong }\end{array}$} & spring & I & I & I & I & I & I & 0.364 & 0.054 & 0.772 \\
\hline & & summer & I & I & I & 0.542 & 0.031 & 0.630 & 0.567 & 0.037 & 0.592 \\
\hline & & autumn & I & I & I & 0.446 & 0.020 & 0.740 & 0.430 & 0.020 & 0.705 \\
\hline & & winter & 0.465 & 0.024 & 2.196 & 0.715 & 0.007 & 0.810 & 0.465 & 0.031 & 0.614 \\
\hline
\end{tabular}
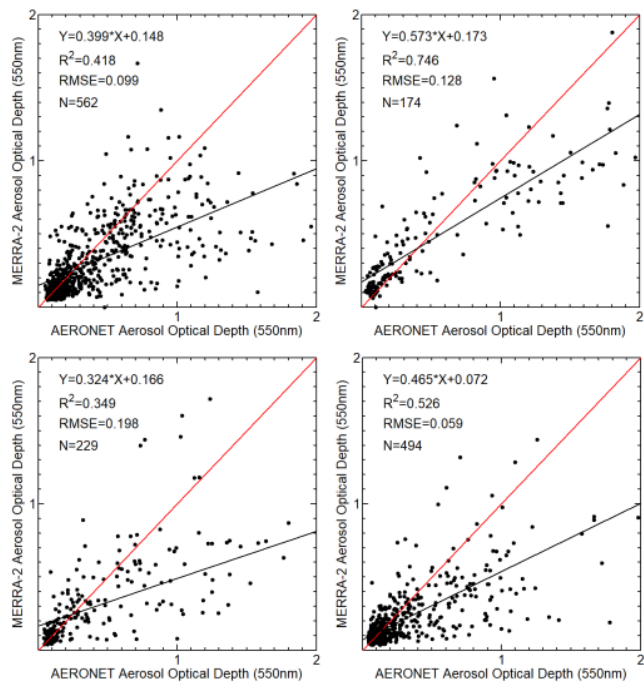

Figure 3. Scatter plots of MERRA-2 AODs versus AERONET AODs in Beijing

(a) spring (b) autumn (c) autumn (d) winter.

The black and red lines represent the slopes of linear regression and the 1:1 lines of scatter plots.
Figure 3 shows the scatter plots of MERRA-2 AODs versus AERONET AODs in Beijing in different seasons. Like Himawari-08 aerosol products, MERRA-2 AODs also show good correlation with AERONET AODs in Beijing. The $\mathrm{R}^{2}$ are $0.418,0.746,0.349$ and 0.526 in the four seasons, respectively. The root mean square errors between Himawari08 and AERONET AODs are very close to zero ( 0.099 for spring, 0.128 for summer, 0.198 for autumn and 0.059 for winter). Besides, the slopes of regression line are lower than unity ( 0.399 for spring, 0.573 for summer, 0.324 for autumn and 0.465 for winter). Like Himawari-08 AOD, MERRA-2 AODs in Beijing tends to underestimate the AODs in all seasons.

From Fig.1-3, it can be inferred that three kinds of aerosol products (MODIS, Himawari-08, MERRA-2) show good correlations with AERONET AODs in Beijing. Furthermore, MODIS aerosol products in Beijing tend to overestimate the AODs in summer and winter and underestimate AODs in spring and autumn, while the Himawari-08 and MERRA-2 aerosol products always underestimated the AODs in all seasons.

Table 2 shows the squared correlation coefficients, the root mean square errors and the regressed slopes of MODIS, Himawari-08 and MERRA-2 comparing with AERONET AODs. It can be concluded from Table 2 that MODIS, 
Himawari-08 and MERRA-2 products have good correlations with AERONET AODs in the other representative stations (i.e. Xianghe, Xuzhou, Taihu and Hong Kong), like Beijing station. For instance, the $\mathrm{R}^{2}$ of Himawari-08 comparing with AERONET AODs in Xianghe are 0.599, 0.772, 0.763 and 0.429 in the four seasons, which are proved by significant testing. The root mean square errors between Himawari-08 and AERONET AODs in Xianghe are very close to zero (0.088 for spring, 0.103 for summer, 0.045 for autumn and 0.074 for winter). Besides, based on the squared correlation coefficients and the root mean square errors of MODIS, Himawari-08 and MERRA-2 comparing with AERONET AODs, it is easily seen that MODIS, Himawari-08 and MERRA-2 AODs have the best applicability for the summer in North China. In addition, Himawari-08 and MERRA-2 AODs have the best applicability for the autumn in East China. The $\mathrm{R}^{2}$ of Himawari-08 comparing with AERONET AODs in Xuzhou are $0.413,0.553,0.571,0.566$ and in Taihu, are $0.408,0.412,0.658$ and 0.154 in the four seasons. The $\mathrm{R}^{2}$ of Himawari-08 comparing with AERONET AODs for the autumn in East China are higher than other three seasons. According to the regressed slopes, we can easily know situations when the AODs are overestimated by the three types of aerosol products. When the regressed slope is higher than unity, the aerosol products tend to overestimate the AODs. It can be clearly seen from Table 2 that AODs are overvalued by MODIS at Beijing, Xianghe and Xuzhou during summer and winter, with the strongest overestimation occurring in winter. As for Taihu and Hong Kong, overestimation only appears in winter for MODIS AOD products. Meanwhile, except for Taihu station in autumn, the Himawari-08 and MERRA-2 aerosol products always underestimate the AODs.

\section{SUMMARY}

This paper compares the AODs of the three types of aerosol products with AERONET AODs at Beijing, Xianghe, Xuzhou, Taihu and Hong Kong respectively. The results indicate that the aerosol optical depths (AODs) obtained by MODIS, Himawari-08, and MERRA-2 in China are basically consistent with the results from AERONET. In general, the accuracy of theses AOD products varies with regions and seasons. MODIS aerosol products tend to overestimate the AODs in summer and winter at Beijing, Xianghe and Xuzhou, and the strongest overestimation are found in winter. As for Taihu and Hong Kong, overestimation only appears in winter for MODIS AOD products. Himawari-08 and MERRA-2 underestimate the AODs in autumn over almost all stations except Taihu.

\section{ACKNOWLEDGEMENTS}

The work is supported by the National Natural Science Foundation of China (41675003 and 91437218) and Priority Academic Program Development of Jiangsu Higher Education Institutions (PAPD).

\section{REFERENCES}

[1] Hansen, J., Sato, M., and Ruedy, R., 1997. Radiative forcing and climate response. Journal of Geophysical Research Atmospheres, 102(D6), pp. 6831-6864.
[2] Kaufman, Y. J., Tanré, D., and Boucher, O., 2002. A satellite view of aerosols in the climate system. Nature, 419(6903), pp. 215-223.

[3] Andreae, M. O., Jones, C. D., and Cox, P. M., 2005. Strong present-day aerosol cooling implies a hot future. Nature, 435(7046), pp. 1187-1190.

[4] Yu, H., Kaufman, Y. J., Chin, M., Feingold, G., Remer, L. A., and Anderson, T. L., et al., 2006. A review of measurement-based assessments of the aerosol direct radiative effect and forcing. Atmospheric Chemistry \& Physics, 6(11), pp. 613-666.

[5] Adler, C. E., and Hadorn, G. H., 2014. The ipcc and treatment of uncertainties: topics and sources of dissensus. Wiley Interdisciplinary Reviews Climate Change, 5(5), pp. 663-676.

[6] W. M. Hao, D. E. Ward, R. A. Susott, R. E. Babbitt, B. L. Nordgren, and Y. J. Kaufman, et al., 2005. Comparison of aerosol optical thickness measurements by modis, aeronet sun photometers, and forest service handheld sun photometers in southern africa during the safari 2000 campaign. International Journal of Remote Sensing, 26(19), pp. 4169-4183.

[7] Kaufman, Y. J., Ichoku, C., Giglio, L., Korontzi, S., Chu, D. A., and Hao, W. M., et al., 2003. Fire and smoke observed from the earth observing system modis instrument--products, validation, and operational use. International Journal of Remote Sensing, 24(8), pp. 1765-1781.

[8] Kaufman, Y. J., Koren, I., Remer, L. A., Rosenfeld, D., and Rudich, Y., 2005. The effect of smoke, dust, and pollution aerosol on shallow cloud development over the atlantic ocean. Proceedings of the National Academy of Sciences of the United States of America, 102(32), pp. 11207.

[9] Yu, H., Kaufman, Y. J., Chin, M., Feingold, G., Remer, L. A., and Anderson, T. L., et al., 2006. A review of measurement-based assessments of the aerosol direct radiative effect and forcing. Atmospheric Chemistry \& Physics, 6(11), pp. 613-666.

[10] Wang, H., Zhang, L., Jiao, S., Zhang, Z., Zhu, Y., and Zhu, C., 2016. Evaluation of the modis aerosol products and analysis of the retrieval errors in china. Plateau Meteorology, 35(3), pp. 810-822.

[11] Zhang, J., Xin, J., Zhang, W., Wang, S., Wang, L., and Xie, W., et al., 2017. Validation of MODIS C6 AODS products retrieved by the dark target method in the BeijingTianjin-Hebei urban agglomeration, china. Advances in Atmospheric Sciences, 34(8), pp. 993-1002.

[12] Yumimoto, K., Nagao, T. M., Kikuchi, M., Sekiyama, T. T., Murakami, H., and Tanaka, T. Y., et al., 2016. Aerosol data assimilation using data from himawari - 8, a next generation geostationary meteorological satellite. Geophysical Research Letters, 43(11).

[13] Bessho, K., Date, K., Hayashi, M., Ikeda, A., Imai, T., and Inoue, H., et al., 2016. An introduction to himawari8/9- Japan's new-generation geostationary meteorological 
satellites. Journal of the Meteorological Society of Japan.ser.ii, 94(2), pp. 151-183.

[14] Fukuda, S., Nakajima, T., Takenaka, H., Higurashi, A., Kikuchi, N., and Nakajima, T. Y., et al., 2013. New approaches to removing cloud shadows and evaluating the $380 \mathrm{~nm}$ surface reflectance for improved aerosol optical thickness retrievals from the GOSAT/TANSO - cloud and aerosol imager. Journal of Geophysical Research Atmospheres, 118(24), pp. 13-13,531.

[15] Zhang, W., Xu, H., \& Zheng, F. (2018). Aerosol optical depth retrieval over East Asia using himawari-8/AHI data. Remote Sensing, 10(1), pp. 137.

[16] Randles, C. A., Da, A. S., Buchard, V., Colarco, P. R., Darmenov, A., and Govindaraju, R., et al., 2017. The MERRA-2 aerosol reanalysis, 1980 - onward, part I: system description and data assimilation evaluation. Journal of Climate, 30(17), pp. 6823-6826.

[17] Buchard, V., Randles, C. A., Silva, A. M. D., Darmenov, A., Colarco, P. R., and Govindaraju, R., et al., 2017. The MERRA-2 aerosol reanalysis, 1980 -- onward, part ii: evaluation and case studies. Journal of Climate, 30(17), pp. 6851-6872.

[18] Zhou, C. Y., Liu, Q. H., Yong, T., Kai, W., and Lin, S., 2009. Comparison between MODIS aerosol product C004 and $\mathrm{C} 005$ and evaluation of their applicability in the north of china. Journal of Remote Sensing, 13(5), pp. 854-872. 